\title{
Identifying Urban Flood Regulation Priority Areas in Beijing Based on an Ecosystem Services Approach
}

\author{
Xiaoyong $\mathrm{Li}^{1,2}{ }^{\mathbb{D}}$, Wenhui Kuang ${ }^{1, *}$ and Fengyun $\operatorname{Sun}^{3}$ \\ 1 Key Laboratory of Land Surface Pattern and Simulation, Institute of Geographic Sciences and Natural \\ Resources Research, Chinese Academy of Sciences, Beijing 100101, China; lixy.16s@igsnrr.ac.cn \\ 2 College of Resources and Environment, University of Chinese Academy of Sciences, Beijing 100049, China \\ 3 School of Ecological and Environmental Sciences, East China Normal University, Shanghai 200241, China; \\ fysun@des.ecnu.edu.cn \\ * Correspondence: kuangwh@igsnrr.ac.cn
}

Received: 10 February 2020; Accepted: 10 March 2020; Published: 15 March 2020

check for updates

\begin{abstract}
Climate change and rapid urbanization have severe impacts on urban flood regulation ecosystem services (UFRES). Quantifying the UFRES has attracted increasing attention for urban sustainable development. However, few studies have focused on how to identify urban flood regulation priority areas. In this study, we simulated urban surface runoff by using the soil conservation services-curve number model, and quantified UFRES supply and demand by using relative indicators (i.e., runoff reduction ratio and urban vulnerability) at the subdistrict scale in Beijing, China. Then, an urban flood regulation priority index was developed by integrating UFRES demand and supply, and further used to identify priority areas. The results show that the mean runoff reduction ratio in Beijing decreased from $38.70 \%$ (for a 1-year rainfall return period) to $24.74 \%$ (for a 100-year rainfall return period). Subdistricts with low UFRES supply were mainly located in the urban central area and the southeastern zone, while subdistricts with high UFRES demand were mainly located in the urban central region. Meanwhile, places with high priority for flood regulation were mainly located in the inner city, and low priority areas were mainly located in northwestern, southwestern, and northeastern Beijing. Our results also imply that the urban flood regulation priority index is an effective indicator to identify urban flood regulation priority areas. These findings could provide urban planners with a comprehensive understanding of UFRES and scientific guidance to improve them.
\end{abstract}

Keywords: Beijing; urban flood regulation; ecosystem services; urbanization

\section{Introduction}

Climate change will increase global exposure to flooding [1,2]. Urban flooding has become one of the most severe natural hazards around the world, especially in coastal cities due to the increase of extreme precipitation events and the rise of sea level [3-5], and more than 600 cities worldwide face serious flood risks [6]. Specifically, the land surface in cities is continuously modified with impervious surfaces that do not allow water to permeate, and result in excessive flooding [7-10]. The flood regulation capability of river systems is also degraded in the urbanization process [11]. Therefore, there is an urgent need to improve urban flood regulation capacity so cities can adapt to climate change during the process of rapid urbanization [12-14].

Ecosystem services refer to the benefits that humans freely gain from natural ecosystems, which include four different types: Provisioning, regulating, cultural and supporting services [15]. Urban flood regulation ecosystem services (UFRES) refer to the capacity of cities to retain storm water and reduce surface runoff as determined by soil, land use, and topography, which can reduce the negative 
impacts of storm water on human safety, infrastructure, and living environment quality in urban ecosystems, such as canopy interception by vegetation, soil water storage, and water storage capacity of wetlands and rivers [16-20]. Studies have reported that urban green spaces (e.g., urban parks and gardens, roads, residential green spaces) can provide flood regulation ecosystem services. For example, it was estimated that urban green space could store $88 \%$ of rainfall in Yixing, China, and vegetation types influenced the runoff regulation capacity of the city [20]. Due to the loss of urban green spaces during the urbanization process in Beijing, urban surface runoff regulation capacity decreased by $6 \%$ from 2000 to 2010 [21]. All these evidences indicate urban green spaces play an important role in enhancing the flood regulation services and improving urban resilience. UFRES is not only related to the integration of urban green-blue infrastructure, but is also affected by urban population density and the pattern of functional zones in the city $[22,23]$.

The ecosystem services-based approach is currently an important way to optimize and manage land to achieve sustainable development goals, especially in urban areas [24-26]. Spatial decision support tools integrating urban ecosystem services were developed to assist urban spatial planning practices [27]. The tradeoffs and synergies among different ecosystem services due to various stakeholders' preferences are also important for urban spatial planning to maximize the benefits of urban green spaces [28]. For example, by integrating the tradeoff and synergies of ecosystem services and GIS, an urban green infrastructure (e.g., rain gardens, bioswales, green roofs) spatial planning model was developed and applied in Detroit [29]. Identifying the priority areas of urban ecosystem services management can provide constructive guidance to enhance the green foundation of cities, thus improve urban ecosystem services and sustainability [30-32]. However, few efforts have attempted to identify urban flood regulation priority areas at the subdistrict scale in urban areas by using an ecosystem services-based approach.

To the best of our knowledge, UFRES has been examined in Beijing [21,33], but previous studies identifying urban flood regulation priority areas have not integrated UFRES supply and demand information at the subdistrict scale. The objectives of this study are to (1) evaluate UFRES supply under different rainfall return periods and UFRES demand in Beijing, and (2) identify urban flood regulation priority areas (UFRPAs) by integrating UFRES supply and demand information. By quantifying UFRES supply and demand, this study addresses the knowledge gap in identifying priority areas for urban flood regulation at the subdistrict scale. The results can provide urban planners scientific guidance to improve UFRES and sustainability.

\section{Study Area}

The study area is located in the Beijing metropolitan area at $39^{\circ} 26^{\prime} \mathrm{N}$ to $41^{\circ} 03^{\prime} \mathrm{N}, 115^{\circ} 25^{\prime} \mathrm{E}$ to $117^{\circ} 30^{\prime}$ E. It occupies a total area of $1369 \mathrm{~km}^{2}$ and includes six districts-Dongcheng, Xicheng, Chaoyang, Fengtai, Shijingshan and Haidian-and 135 subdistricts or towns (Figure 1). The total population in 2018 was approximately 12.09 million, and more than $99 \%$ lived in urban areas [34]. Since the implementation of China's reform and opening-up policies, Beijing has experienced a rapid urbanization process and the urbanization rate reached $86.5 \%$ in 2018 . The total built-up land and impervious surface areas have increased by more than 1100 and $700 \mathrm{~km}^{2}$, respectively, in the past 40 years [35-37]. Dramatic increase in impervious surface and decrease of green space have intensified the urban flood risk and amount of water-logging. The climate of Beijing is temperate and monsoonal and is characterized by hot summers and cold winters. The mean annual temperature is $12{ }^{\circ} \mathrm{C}$ and the mean annual precipitation varies from $400-800 \mathrm{~mm} \mathrm{yr}^{-1}$, of which nearly $80 \%$ occurs between June and September $[21,38]$. Previous studies have shown that both precipitation and annual days of rainstorms in Beijing have decreased gradually in the past 50 years [39]. However, heavy rainstorms occurred more than 20 times in the urban areas of Beijing in the past 10 years, which resulted in serious waterlogging disasters. More specifically, rainstorms occurred on 21 July 2012 and 20 July 2016, both resulting in severe water-logging and socioeconomic loss [40,41]. In 2016, Beijing was chosen as an example city to implement an idea called "Sponge City" to improve urban flood mitigation capacity 
and realize the goal of "no ponding under light rain and no water-logging under heavy rain." Under these circumstances, it is necessary to evaluate UFRES to support urban green infrastructure and low-impact development planning.

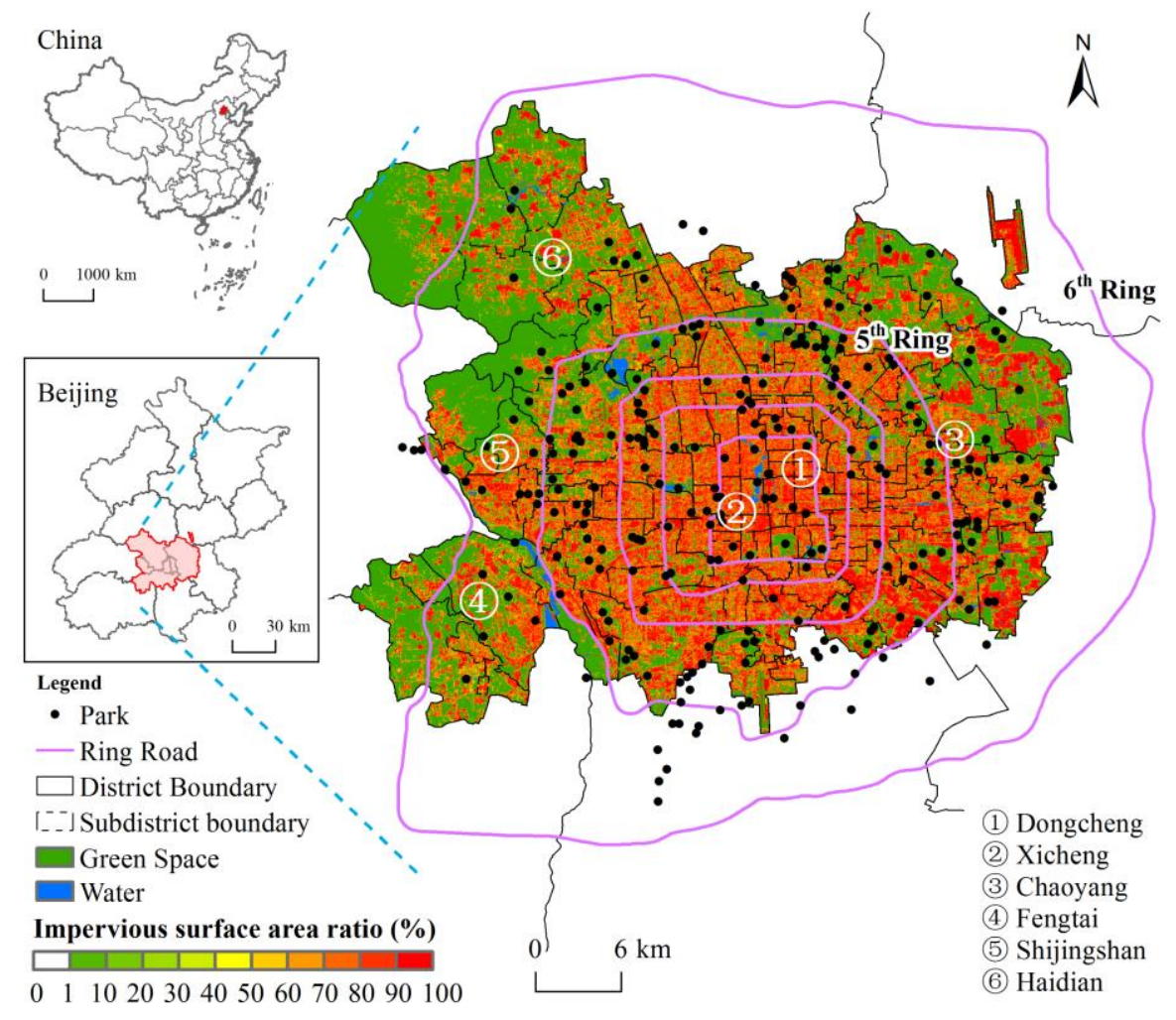

Figure 1. Location and urban land cover of the study area.

\section{Data and Methods}

The flow chart in Figure 2 shows the procedures adopted in this study to identify urban flood regulation priority areas in Beijing. First, we collected the datasets used in this study. Second, we processed the Landsat image, land use and population data to evaluate UFRES. Third, we evaluated UFRES supply and demand by using indicators of runoff reduction ratio and urban vulnerability. Then, we calculated an urban flood regulation priority index to identified priority areas and analyzed the spatial pattern of urban flood regulation priority areas. Finally, we discussed the efficiency of the priority index and the role of urban green space in urban flood regulation. 


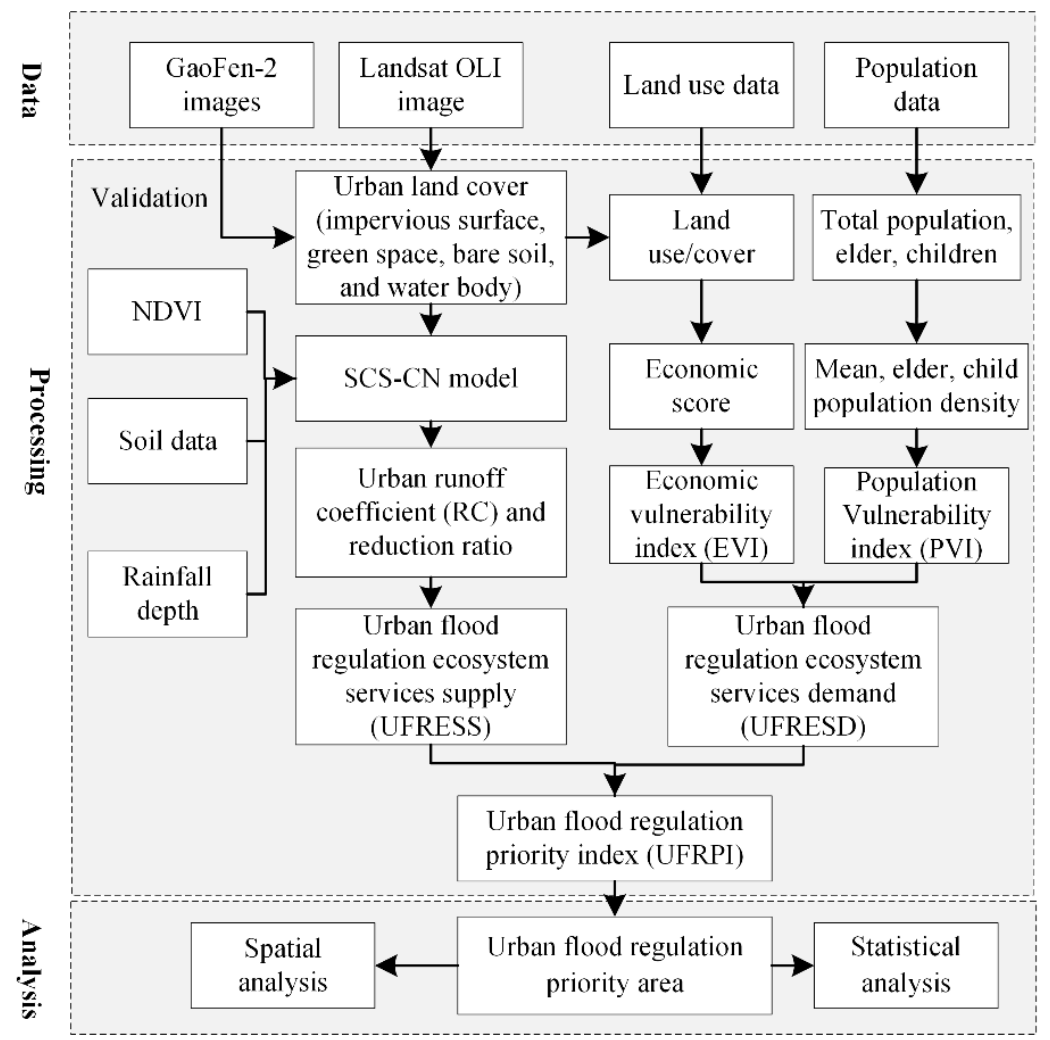

Figure 2. Flow chart to identify urban flood regulation priority areas (NDVI, normalized difference vegetation index; SCS-CN, soil conservation service-curve number).

\subsection{Data Sources and Pre-Processing}

In this study, Landsat 8 OLI imagery, China land use/cover datasets (CLUDs) of 2015, and other auxiliary data were used to evaluate UFRES supply and demand.

(1) Landsat imagery processing and urban land cover extraction

Landsat 8 OLI imagery covering Beijing (Path/Row: 123/032, 14 September 2017) was used to extract the urban land cover fractions data. In this study, urban land cover was classified into four types: Impervious surface area (ISA), green space (GS), bare soil, and water body. First, radiometric calibration and FLAASH atmosphere calibration were conducted for the Landsat 8 OLI image in the environment for visualizing images (ENVI, Version 5.3) software. Then, a linear spectral unmixing method [42,43] was used to extract high/low albedo fractions, GS fraction, and soil fraction in ENVI 5.3. A modified normalized difference water index [44] was calculated to extract water bodies. We further processed the data by building a decision tree to extract land cover, detailed information about the method can be found in $[43,45]$.

(2) High-resolution images

To validate the accuracy of urban land cover fraction data, 100 random points in the study area were generated using a spatial analyzing approach in ArcGIS 10.3 software, and each site was processed as a square with an area of $90 \mathrm{~m} \times 90 \mathrm{~m}$. For each sample site, the ISA, GS, bare soil, and water bodies from 2017 were visually interpreted by using GaoFen-2 images ( $0.8 \mathrm{~m}$ resolution, acquired 9 June 2017). The accuracy assessment results showed that the root mean square errors of ISA and GS were lower than $10 \%$, which indicated that the data were appropriate for further analysis.

(3) China land use/cover datasets for Beijing

CLUDs in 2015 were developed by utilizing remote sensing satellite imagery data, such as Landsat 8 OLI images and GaoFen-2. The datasets include six classes-cropland, forest, grassland, water body, built-up land, and unused land-and 25 subclasses. The accuracies of the six classes of CLUDs were higher than $90 \%$, which meets the requirement of the user mapping accuracy at 1:1,000,000 scale [46,47]. 
(4) Other datasets

Soil data were obtained from the Resource and Environment Data Cloud Platform, with a scale of 1:1,000,000 [48], and used to obtain the hydrological properties of soil. The population data at subdistrict scale, including total population, child population (ages 0 to 14 years old) and elder population (ages over 60 years old) were downloaded from the Beijing Municipal Bureau of Statistics [49].

\subsection{Urban Runoff Simulation}

In this study, we used the soil conservation service curve number (SCS-CN) model to simulate urban runoff under different scenarios, and previous research demonstrates that this model is easy to implement and accurately simulates urban runoff [20,50-52]. The runoff coefficient and runoff depth were calculated using the following equations:

$$
\begin{gathered}
R C=Q / P \\
\left\{\begin{array}{c}
Q=\frac{\left(P-I_{a}\right)^{2}}{P-I_{a}+S}\left(P \geq I_{a}\right) \\
Q=0 \quad\left(P<I_{a}\right) \\
S=\frac{25400}{C N}-254 \\
I_{a}=\lambda \times S
\end{array}\right.
\end{gathered}
$$

where $R C$ refers to runoff coefficient, $Q$ is the direct surface runoff depth $(\mathrm{mm}), P$ is the precipitation $(\mathrm{mm}), S$ is the potential maximum water storage in soil $(\mathrm{mm}), C N$ is the curve number ranging from 0 to $100, I_{a}$ is the soil abstraction $(\mathrm{mm})$, and $\lambda$ is the initial abstraction coefficient set as 0.2 [50].

The $C N$ value is a key parameter of the SCS-CN model, which directly reflects the condition of soil. It is determined by soil moisture and soil type. In this study, we calculated the direct runoff under moderate antecedent moisture conditions (AMC-II). The $C N$ values were generated using the method proposed in [42], which can be expressed as the following equation:

$$
\mathrm{CN}=a_{\text {isa }} \times \mathrm{CN}_{\text {isa }}+a_{\text {veg }} \times \mathrm{CN}_{\text {veg }}+a_{\text {soil }} \times \mathrm{CN}_{\text {soil }}
$$

where $C N$ refers to the composite $C N$ value; $a_{i s a}, a_{v e g}$ and $a_{\text {soil }}$ are the fractions of impervious surface, vegetation, and soil, respectively; and $C N_{i s a}, C N_{v e g}$, and $C N_{\text {soil }}$ are the $C N$ values of impervious surface,

\begin{tabular}{|c|c|c|c|}
\hline & Land Cover & & CN Value \\
\hline \multirow{12}{*}{ Green space } & Impervious surface & & 98 \\
\hline & \multirow{4}{*}{ NDVI $>0.65$} & $a_{\text {veg }} \leq 50 \%$ & 66 \\
\hline & & $50 \%<\mathrm{a}_{\mathrm{veg}} \leq 75 \%$ & 60 \\
\hline & & $a_{\text {veg }}>75 \%$ & 55 \\
\hline & & $a_{\text {veg }} \leq 50 \%$ & 73 \\
\hline & \multirow{2}{*}{$0.57<\mathrm{NDVI} \leq 0.65$} & $50 \%<\mathrm{a}_{\mathrm{veg}} \leq 75 \%$ & 65 \\
\hline & & $a_{\text {veg }}>75 \%$ & 58 \\
\hline & \multirow{2}{*}{$0.40<\mathrm{NDVI} \leq 0.57$} & $a_{\text {veg }} \leq 50 \%$ & 81 \\
\hline & & $a_{\text {veg }}>50 \%$ & 78 \\
\hline & $\mathrm{NDVI} \leq 0.4$ & & 74 \\
\hline & Soil & & 91 \\
\hline & Water & & 0 \\
\hline
\end{tabular}
vegetation, and soil, respectively. In addition, the $C N$ values of water, impervious surface, and soil were set as 0,98 , and 91 , respectively $[50,53]$. The $C N$ values use in this study for different land uses/covers are shown in Table 1.

Table 1. Curve number $(\mathrm{CN})$ values of different land covers.

Note: NDVI, normalized difference vegetation index. 


\subsection{Evaluating the Supply for Urban Flood Regulation Ecosystem Services}

Previous studies have created difference indicators (i.e., runoff reduction capacity, absorption ratio, runoff reduction volume $[21,33,54,55])$ to characterize UFRES supply (UFRESS). Following previous studies, urban runoff reduction capacity was used to represent UFRESS [21,50,55]. To estimate the surface runoff reduction capacity of urban green space in each subdistrict, we calculated two indicators: Runoff volume reduced by urban green space $(\Delta v)$ and the runoff reduction ratio. The UFRES indicator can be expressed with the following equation:

$$
\text { UFRESS }=\Delta v \times(0.001 \times P \times A)^{-1} \times 100 \%
$$

where UFRESS refers to the surface runoff reduction ratio of each subdistrict (the value range is from $0 \%$ to $100 \%), \Delta v$ refers to the surface runoff reduction volume $\left(\mathrm{m}^{3}\right)$ of each subdistrict, $P$ is the precipitation $(\mathrm{mm})$ of different rainfall scenarios, and $A$ refers to the area $\left(\mathrm{m}^{2}\right)$ of each subdistrict.

Runoff reduction volume $(\Delta v)$ can be expressed as the following equation:

$$
\Delta v=\sum_{i=1}^{n} 0.001 \times\left(Q_{i s a}-Q_{i}\right) \times A_{i}
$$

where $\Delta v$ refers to the surface runoff reduction volume of each subdistrict, $Q_{i s a}$ is the surface runoff depth generated by $100 \%$ of the impervious surface, $Q_{i}$ is the surface runoff depth of each pixel, and $A_{i}$ is the area of each pixel $(30 \mathrm{~m} \times 30 \mathrm{~m})$.

A high UFRESS value means that the existing green space in the subdistrict provides more potential UFRES. Here, UFRES supply runoff reduction capacity was evaluated under different rainfall scenarios. We used the storm intensity formula for Beijing [56] to calculate the rainfall depths of four scenarios: $39.7 \mathrm{~mm}$ (1-year rainfall return period), $62.4 \mathrm{~mm}$ (10-year rainfall return period), $72.1 \mathrm{~mm}$ (25-year rainfall return period), and $104.4 \mathrm{~mm}$ (100-year rainfall return period), and the rainfall duration was set as $120 \mathrm{~min}[50,56]$.

\subsection{Evaluating the Demand for Urban Flood Regulation Ecosystem Services}

Generally, UFRES demand is evaluated using flood risk level or vulnerability level $[54,55,57]$. In this study, we used a simplified urban vulnerability index to quantify UFRES, which was calculated by combining the population vulnerability and economic vulnerability indexes. Then it was used to represent the demand (UFRESD). The UFRESD index can be expressed with the following equation:

$$
\operatorname{UFRESD}_{i}=a * P V I_{i}+b * E V I_{i}
$$

where $U F R E S D_{i}$ is the UFRES demand in subdistrict $i ; P V I_{i}$ and $E V I_{i}$ are the area population vulnerability and economic vulnerability of subdistrict $i$, respectively; $\mathrm{a}$ and $\mathrm{b}$ refer to the weights of the population vulnerability and economic vulnerability, respectively, which we set as equal for the two variables.

Following previous studies, we used mean population density, elder population density, and child population density to calculate population vulnerability [58]. It can be expressed with the following equation:

$$
\mathrm{PVI}_{i}=\alpha * \text { Pop }_{d}+\beta * \mathrm{Old}_{d}+\gamma * \text { Child }_{d}
$$

where Pop $_{d}, \operatorname{Old}_{d}$, and Child $d$ are the mean, elder, and child population densities, respectively, which were evaluated based on the population conditions of each subdistrict. $\alpha, \beta$, and $\gamma$ refer to the weights of the mean, elder, and child population densities, respectively, which we set as equal for the three variables.

Detailed digital economic data at high resolution (subdistrict scale) were unavailable to evaluate economic vulnerability in our study area. However, economic vulnerability was mainly based on publicly available land use/cover data [59]. Here, we used land use/cover data with different 
economic scores to evaluate economic vulnerability. Economic vulnerability can be expressed with the following equation:

$$
E V I_{i}=\sum_{j=1}^{n} \text { EconomicScore }_{j}
$$

where $E V I_{i}$ is the economic vulnerability of subdistrict $i$ and EconomicScore $j$ is the economic vulnerability score of $j$ pixel in subdistrict $i$. We assume that undeveloped land (forest, grass, and pasture) and cropland have relatively low vulnerability to flooding (score 1-3), whereas land with low-density (20\%-50\%) ISA, medium-density (50\%-80\%) ISA, and high-density $(>80 \%)$ ISA have higher vulnerabilities (score 5-8) (Table A1). Detailed information about vulnerability levels can be found in [59].

\subsection{Identifying Urban Flood Regulation Priority Areas}

To identify the priority areas of urban flood regulation, an urban flood regulation priority index (UFRPI) was calculated by integrating the supply of and demand for UFRES. To support the "sponge city" construction, the urban drainage system in Beijing was reconstructed so it could still work effectively during a 10-year rainfall return period. Therefore, in this study, the UFRES supply for a 10 -year rainfall return period was used to calculate the priority index. It can be expressed with the following equation:

$$
\text { UFPRI }_{i}=\sqrt{\text { UFRESD }_{i} / \text { UFRESS }}
$$

where $U F P R I_{i}$ refers to the priority index of urban flood regulation in subdistrict $i$ and $U F R E S D_{i}$ and UFRESS $_{i}$ are the demand and supply indices of UFRES, respectively.

To identify the hotspot areas of urban flood regulation priority areas, the quantile method was mostly used to present the high values or low values of UFRESS and UFRESD [54,57]. For example, previous studies regarded the top $20 \%$ areas of UFRESD or UFRESS as a hotspot or priority area [57]. However, this method only identified the areas where both UFRESD and UFRESS are high. In this study, spatial clustering analysis-Local Moran's I index [60], which considers the neighboring effect-was used to identify urban flood regulation priority areas. The index can be expressed with the following equation:

$$
I_{i}=\frac{x_{i}-\bar{X}}{S_{i}^{2}} \sum_{j=1}^{n} w_{i, j}\left(x_{j}-\bar{X}\right)
$$

where $I_{i}$ is Local Moran's I statistic for subdistrict $i ; x_{i}$ and $x_{j}$ refer to the urban flood regulation priority index in subdistrict $i$ and $j ; w_{i, j}$ is a spatial weight matrix with $n$ dimensions, which represents the spatial relation between subdistrict $i$ and $j ; \bar{X}$ is the mean priority index of all subdistricts; and $S_{i}^{2}$ is the variance. The Local Moran's I statistics include four categories: high-high $(\mathrm{H}-\mathrm{H})$, high-low $(\mathrm{H}-\mathrm{L})$, low-high (L-H), and low-low (L-L). In this study, the subdistricts with H-H values were extracted for further analysis.

\section{Results}

\subsection{Analysis of Urban Surface Runoff for Different Rainfall Scenarios}

Urban surface runoff under four rainfall scenarios was estimated by utilizing the urban land cover and the SCS-CN model. The spatial distributions of the runoff coefficients under the 1-year, 10-year, 25-year, and 100-year rainfall return periods are shown in Figure 3. In general, urban surface runoff coefficient increases with the increase of rainfall intensity, and the mean runoff coefficient ranges from 0.39 to 0.61 under the 1-year and 100-year rainfall return periods, respectively. Spatially, the urban surface runoff coefficient in the urban center increased significantly with the increase of rainfall intensity. The results also show that urban runoff coefficient decreases gradually along the urban-rural gradient (Figure 3). 

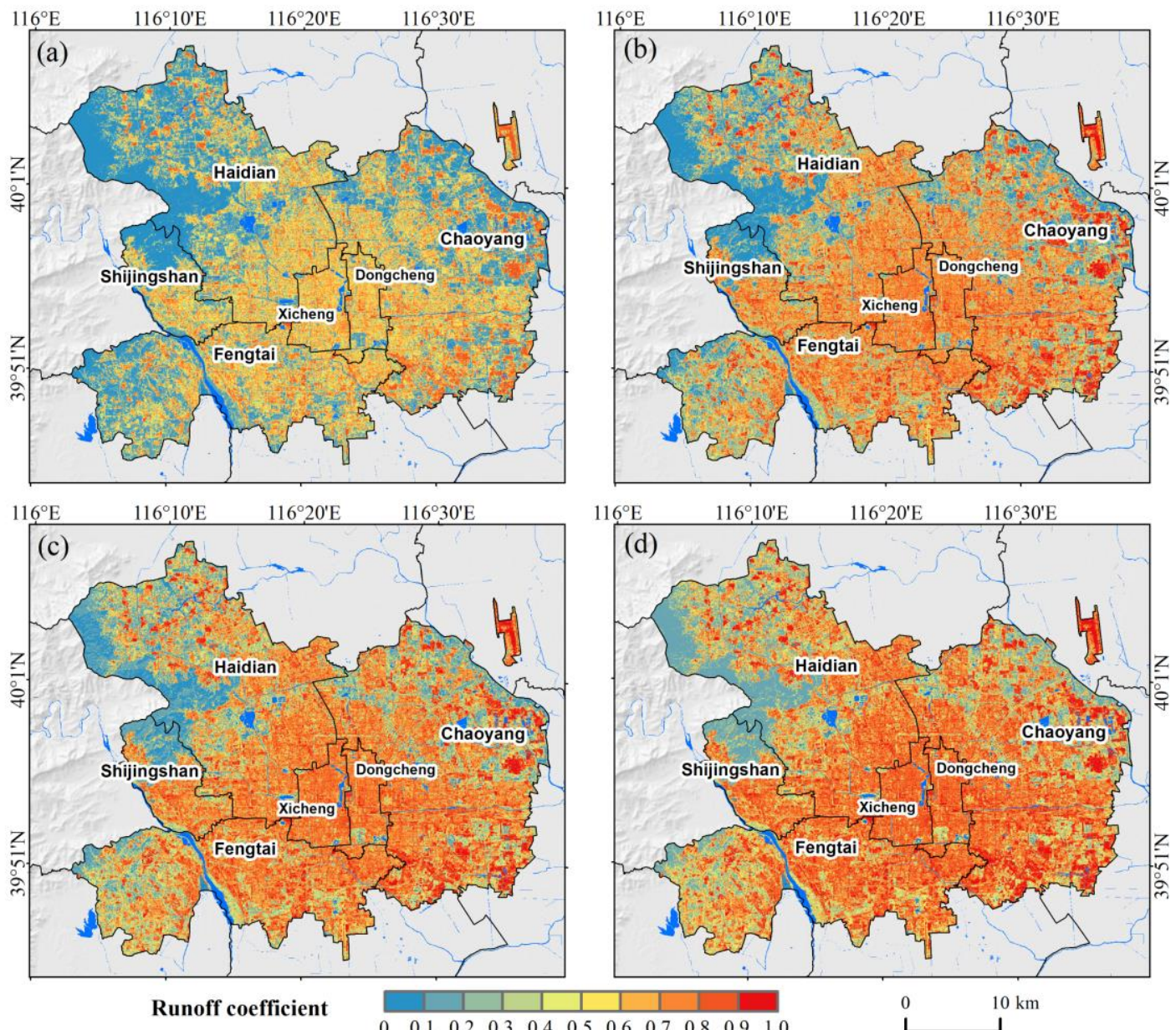

$116^{\circ} 30^{\prime} \mathrm{E}$

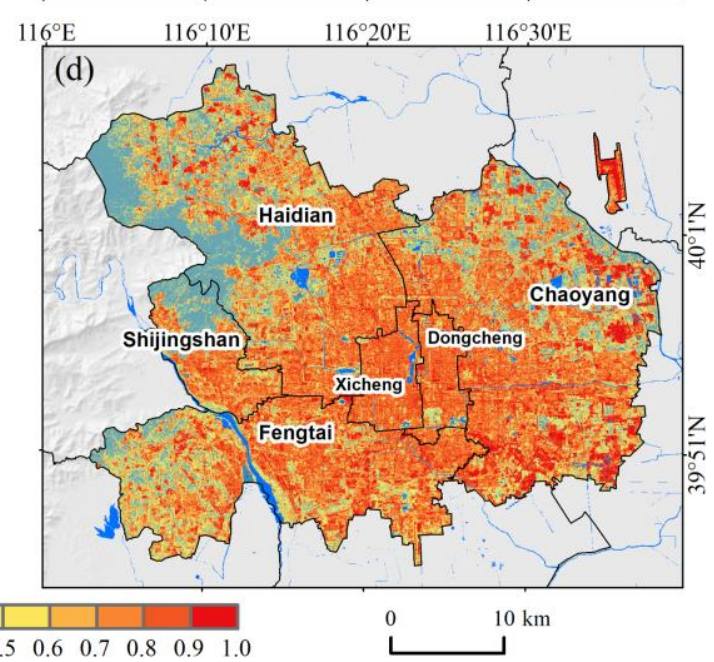

Figure 3. Spatial distributions of the urban runoff coefficients for 1-year (a); 10-year (b); 25-year (c); and 100-year $(\mathbf{d})$ rainfall return periods.

Due to different land cover compositions, the runoff coefficients varied among the six districts. It is obvious that Dongcheng District, with the highest impervious surface percentage, has the highest runoff coefficient, while Haidian District, with the highest green space percentage, has the lowest runoff coefficient (Figure 4). This result indicates that urban impervious surface and green space play opposite roles in mitigating runoff, and green space plays a positive role in regulating runoff to some extent. Under the 10-year rainfall return period, the runoff coefficient in Dongcheng District was 0.67, while the runoff coefficient in Haidian District was lower by 0.22 . This is mainly because the impervious surface percentage in Dongcheng was 30.9\% higher than that in Haidian (Figure 4). 


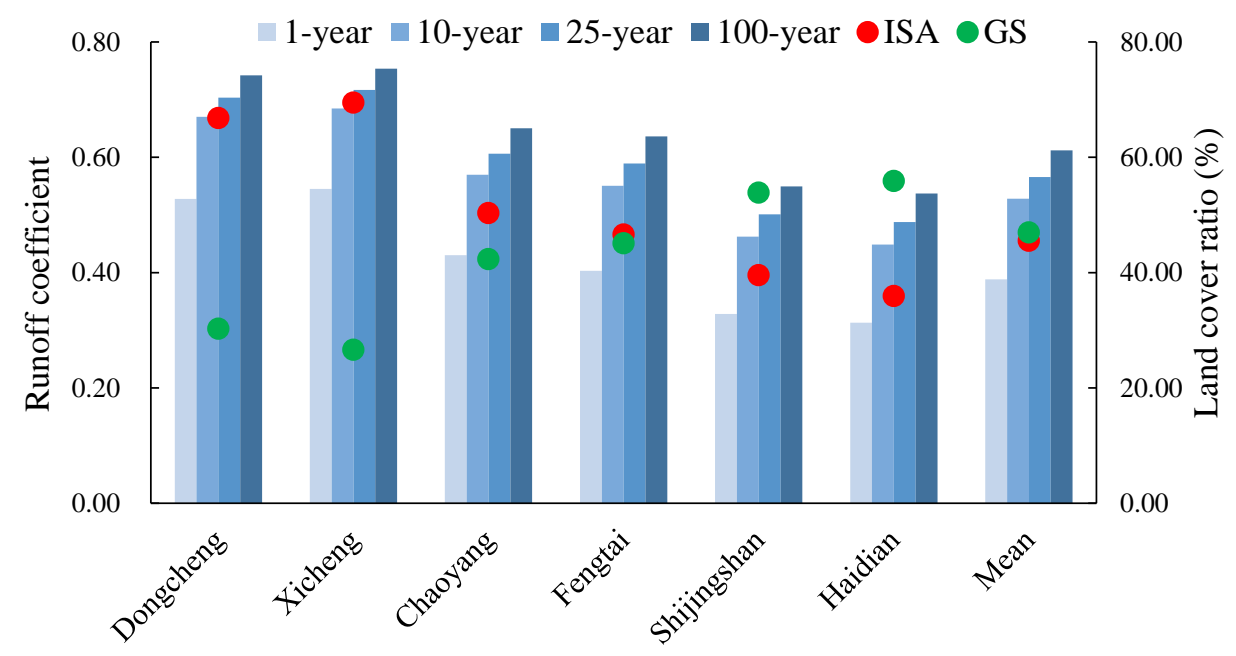

Figure 4. The urban runoff reduction ratio of six districts in Beijing for 1-year, 10-year, 25-year, and 100-year rainfall return periods (ISA, impervious surface area; GS, green space).

\subsection{Supply for Urban Flood Regulation Ecosystem Services under Different Rainfall Scenarios in Beijing}

The UFRES supply capacity is mainly determined by rainfall depths, soil conditions, and land cover characteristics. The spatial pattern of the UFRES supply capacity under four rainfall scenarios is shown in Figure 5. The subdistricts with high UFRES supply capacity were mainly located in the western part of the study area, and subdistricts with low UFRES supply capacity were mainly located in the central and southeast areas. It should be noted that the UFRES supply in subdistricts located in the central and southeastern parts of the study area decreased quickly with the increase of rainfall intensity. Therefore, some stormwater management measures should be implemented to improve the surface runoff regulation capacity.

As shown in Table 2, mean runoff reduction ratios of different rainfall return periods vary. For the 1-year rainfall return period $(39.7 \mathrm{~mm})$, the mean runoff reduction ratio is $38.70 \%$, and the value decreased by $14 \%$ for the 100 -year rainfall return period, indicating that the supply capacity of UFRES decreases with increasing rainfall depth in Beijing, while the standard deviation (STD) of UFRES supply changes a little, decreasing by $0.6 \%$ (Table 2). Meanwhile, the surface runoff reduction ratios in six districts also vary due to the divergence of land cover percentage and rainfall intensity. Both the mean runoff reduction ratio and its STD in Shijingshan District are the highest $(38.09 \%$ and $12.53 \%$, respectively, for a 10-year rainfall return period), while those in Xicheng District are the lowest $(20.89 \%$ and $4.69 \%$, respectively, for a 10 -year rainfall return period) due to its high percentage $(66.80 \%)$ of impervious surface (Table 2). More specifically, the UFRES supply capacity in Dashilan Subdistrict (subdistrict highlighted with red bound line in Figure 5) is the lowest with runoff reduction ratio of $11.58 \%$ (for 10-year rainfall return period) due to its high impervious surface ratio $(84.45 \%)$, where should be regarded as the urban flood regulation priority area. 

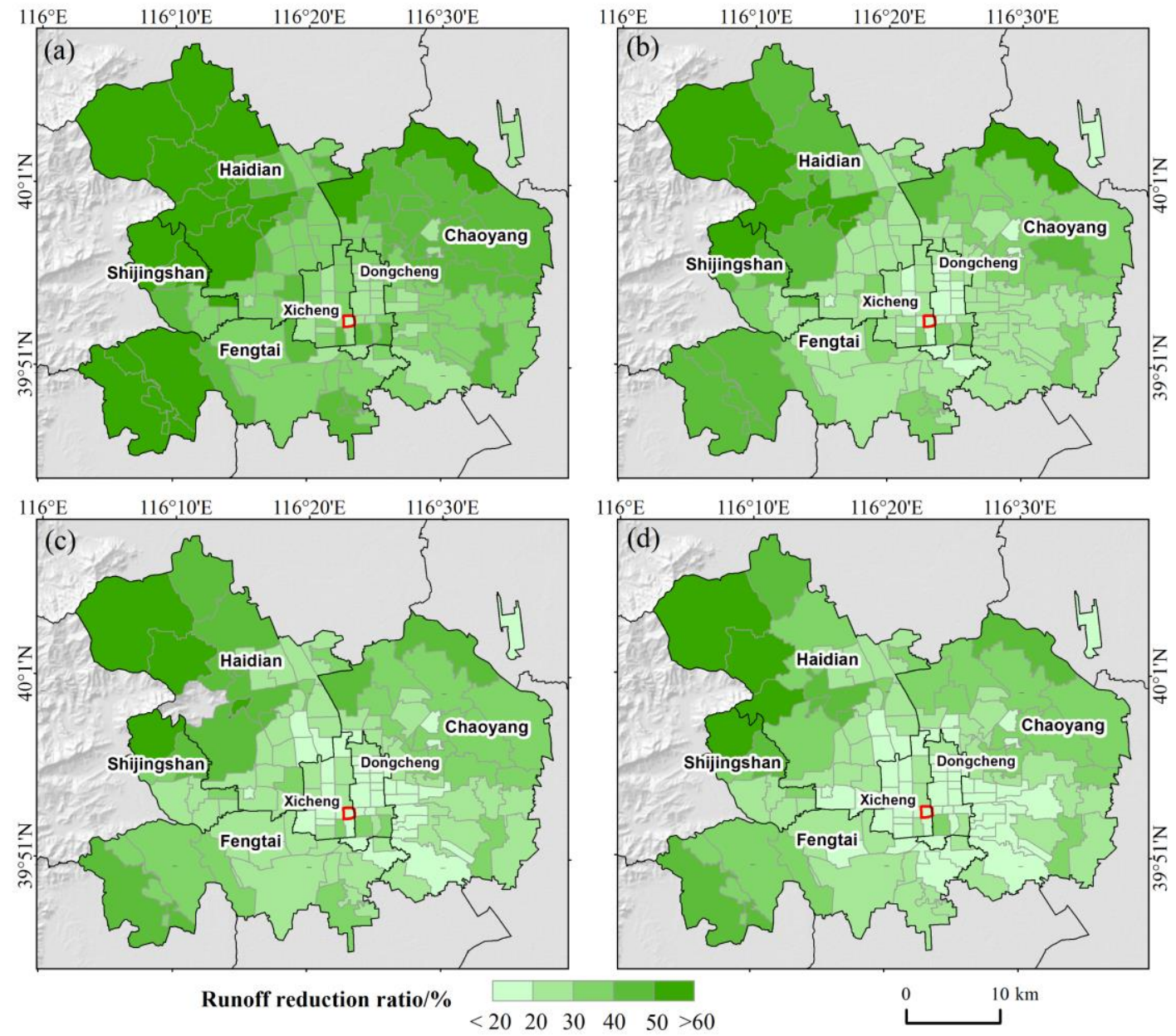

Figure 5. Spatial pattern of urban flooding regulation ecosystem services supply for 1-year (a); 10-year (b); 25-year (c); and 100-year (d) rainfall return periods. Boundary of Dashilan Subdistrict is shown in red.

Table 2. The urban runoff reduction ratio of six districts in Beijing for 1-year, 10-year, 25-year, and 100-year rainfall return periods.

\begin{tabular}{ccccccccc}
\hline \multirow{2}{*}{ Districts } & \multicolumn{2}{c}{ 1-Year } & \multicolumn{2}{c}{ 10-Year } & \multicolumn{2}{c}{ 25-Year } & \multicolumn{2}{c}{ 100-Year } \\
& Mean & STD & Mean & STD & Mean & STD & Mean & STD \\
\hline Dongcheng & 31.22 & 6.27 & 21.62 & 5.92 & 20.01 & 6.29 & 17.96 & 5.29 \\
Xicheng & 30.12 & 4.99 & 20.89 & 4.69 & 19.29 & 5.29 & 17.53 & 4.40 \\
Chaoyang & 38.32 & 7.93 & 28.69 & 7.79 & 26.66 & 7.93 & 24.34 & 7.10 \\
Fengtai & 40.03 & 8.63 & 29.97 & 8.46 & 27.92 & 8.24 & 25.34 & 7.68 \\
Shijinshan & 47.53 & 11.33 & 38.09 & 12.53 & 35.79 & 12.26 & 33.10 & 12.02 \\
Haidian & 44.38 & 13.20 & 34.71 & 14.05 & 32.56 & 13.87 & 29.92 & 13.27 \\
Mean & 38.70 & 10.62 & 29.07 & 10.81 & 27.09 & 10.70 & 24.74 & 10.02 \\
\hline
\end{tabular}

Note: STD, standard deviation.

\subsection{Demand for Urban Flood Regulation Ecosystem Services in Beijing}

In this study, UFRESD is determined by population vulnerability and economic vulnerability. Figure 6 shows the spatial pattern of urban population vulnerability, economic vulnerability, and UFRES demand. The subdistricts with a high UFRESD are mainly located in Dongcheng and Xicheng Districts. This is mainly because the population in the central city was more concentrated than that in 
suburban areas, especially the proportion of minority groups (such as children and elders) (Figure 6a). More specifically, the top 10 subdistricts that demand the most UFRES also have a large number of children and elders, and their occupancies are higher than 15\% each. Meanwhile, the subdistricts with low UFRESD were mainly distributed in the northwestern part of Haidian District and the northeastern part of Chaoyang District, where population density was low and natural land accounted for over $80 \%$ of the total area. Yongding-Road Subdistrict (Figure 6) had the highest UFRESD value, mainly due to its high population density $\left(49,346\right.$ persons $\left./ \mathrm{km}^{2}\right)$, high proportion of elderly people $(15.86 \%)$, and high impervious surface ratio $(78.42 \%)$.

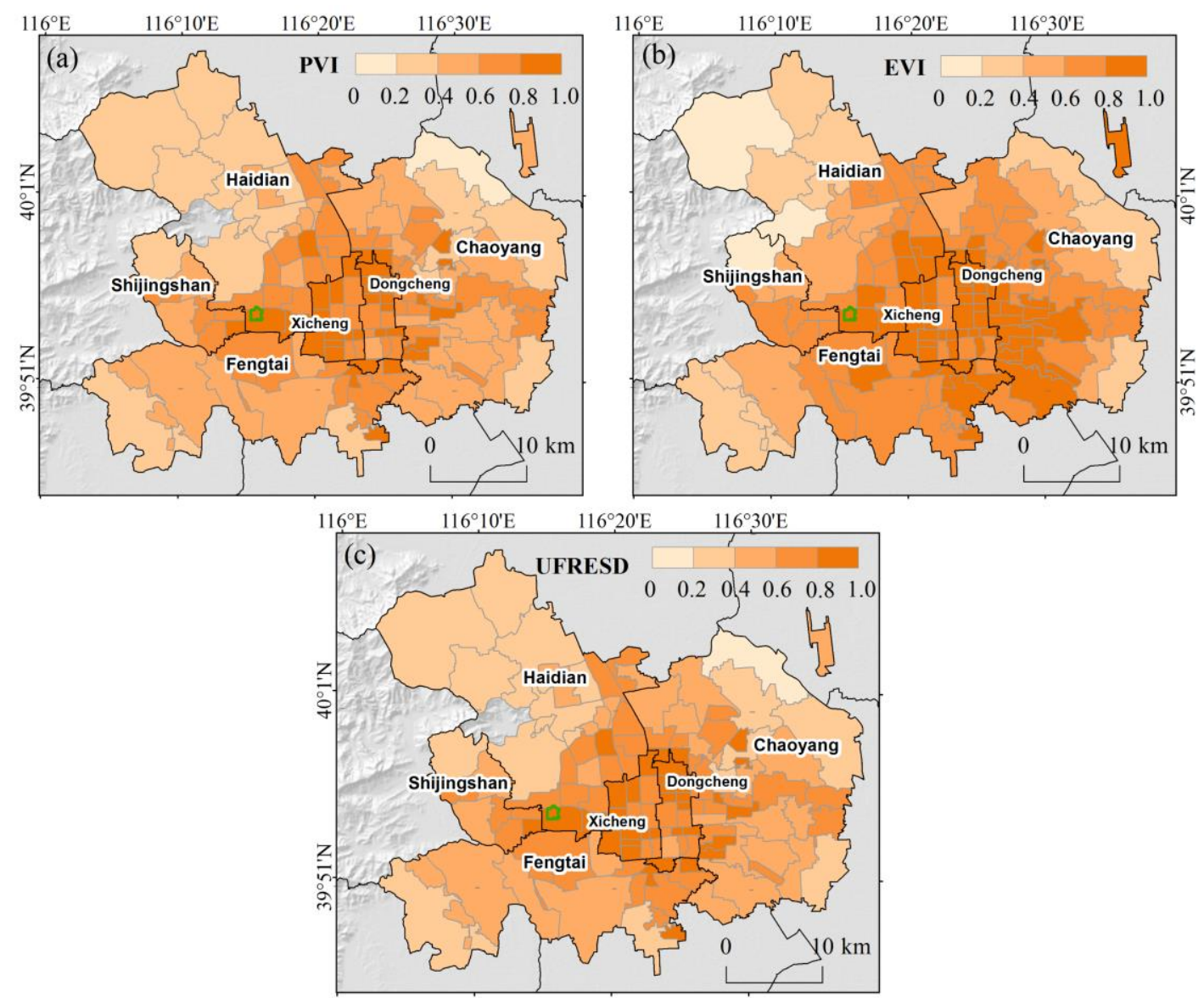

Figure 6. Spatial patterns of (a): Urban population vulnerability, (b): economic vulnerability, and (c): demand for urban flooding regulation ecosystem services (UFRESD) (PVI, population vulnerability index; EVI, economic vulnerability index). The boundary of Yongding-Road Subdistrict is shown in green.

\subsection{Analysis of Urban Flood Regulation Priority}

In this study, we calculated UFRPI by integrating UFRES supply and demand. In general, the mean UFRPI of the study area was 1.54; Xicheng and Shijingshan had the highest value (1.98) and the lowest value (1.33), respectively. Spatially, urban flood regulation priority decreased with increasing distance to the urban center. The subdistricts with high priority values were mainly located in Dongcheng and Xicheng Districts. While, the subdistricts with low priority values were mainly distributed in northwestern Haidian District and northeastern Chaoyang District, where urban flood regulation supply is high and flood regulation demand is low (Figure 7a). 

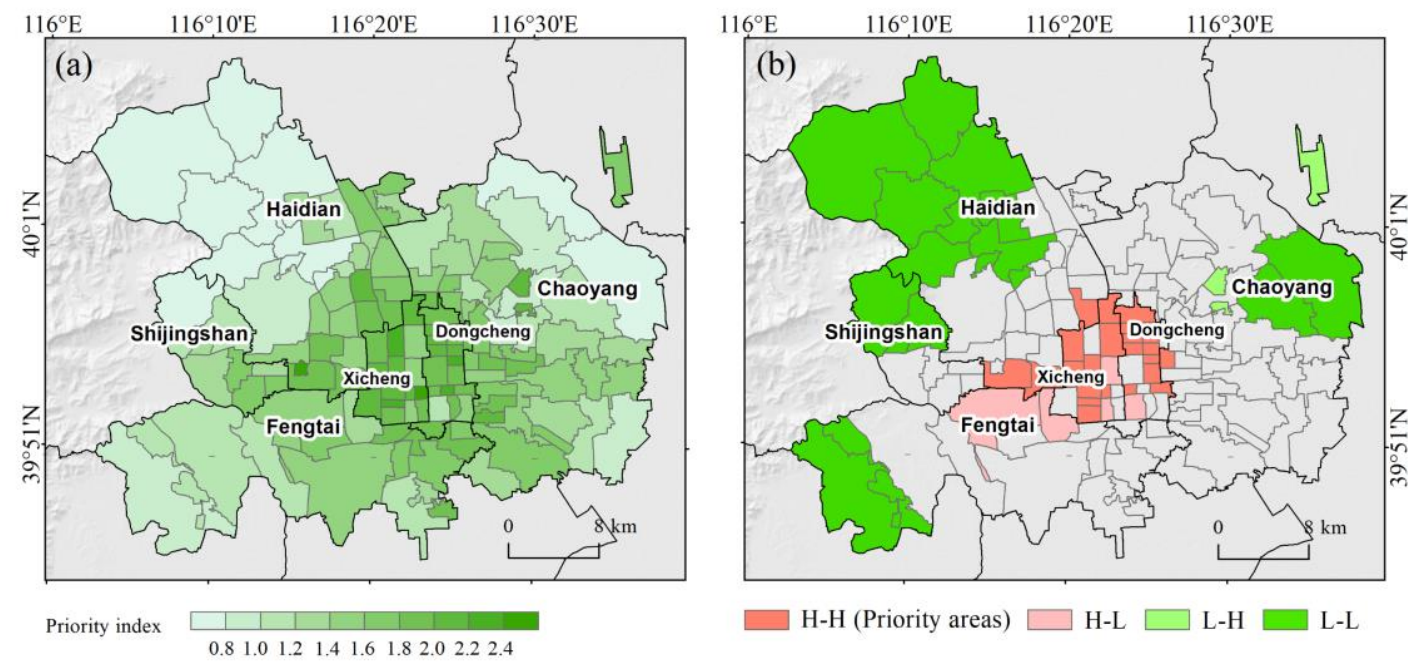

Figure 7. Urban flooding regulation priority index map (a), subdistricts (in dark green) have high priority index values; spatial clustering map of urban flooding regulation priority index (b), priority areas are the cluster of the subdistricts with high priority index values.

Results from Local Moran's I analysis indicate that the high-priority clustering area $(\mathrm{H}-\mathrm{H})$ occupied 23 subdistricts, mainly distributed in the inner city, especially in Dongcheng and Xicheng Districts (Figure 7b). Most subdistricts have relatively high demand and low supply UFRES, which indicates that some stormwater management measures (e.g., green infrastructure, drainage improvement, low-impact development techniques) should be implemented here. The low-priority areas (L-L) occupy 17 subdistricts located in the suburban districts and have relatively high proportions of green space (i.e., trees, grassland, cropland), which should function as key areas for ecosystem services such as water retention and urban flood regulation to keep the inner city safe (Figure 7b).

\section{Discussion}

\subsection{An Effective Approach to Identify Urban Flood Regulation Priority Areas by Integrating UFRES Supply and Demand}

Identifying subdistrict-scale area with priority in urban flood regulation is very important, especially through a scientific and easily implemented approach. Ecosystem services-based approaches are also widely applied to achieve land use management by systematically quantifying ecosystem service supply and demand $[24,27,29,31]$. In urban areas, the spatial planning of green infrastructure based on an ecosystem services approach has been developed in recent years, but there are still many uncertainties. More specifically, it is difficult to calculate the priority index due to the uncertainty of the weights for ecosystem services supply and demand. Given there is no value judgment about which one is more important for these two variables in this study, we developed a UFRPI by using a geometric method, instead of the arithmetic aggregation method, to integrate the UFRES supply and demand information $[29,55]$. This method can increase the capability of the approach to identify critical areas [61]. In addition, previous research mainly used a natural breakpoints method to identify urban flood regulation hotspot areas [57]. We used spatial clustering analysis to produce a spatially explicit map of urban flood regulation priority areas $(\mathrm{H}-\mathrm{H})$ and L-L, H-L, and L-H areas, which is helpful to identify the subdistricts for sharing interregional UFRES [54].

We further examined the relationships between UFRES supply/demand and UFRPI. There is a linear and positive correlation between UFRES demand and UFRPI, which indicates that subdistricts with high UFRES demand, or urban vulnerability, generally have high UFRPI (Figure 8a). Meanwhile, the relationship between UFRES supply and UFRPI is non-linear with a negative correlation, which indicates that the subdistricts with low UFRES supply, or runoff reduction ratio, also have low UFRPI 
(Figure 8b). Our results are consistent with the assumption that an urban flood regulation priority area should distribute in a high demand and high flood-risk area [33], and this study further demonstrates UFPRI is an effective indicator to identify urban flood regulation priority areas. Therefore, urban planners and decision makers could apply this easily implemented approach to search for hotspots of urban flood regulation and classify the subdistricts or parcels into different priority levels, which would improve the efficiency of urban sustainable management.
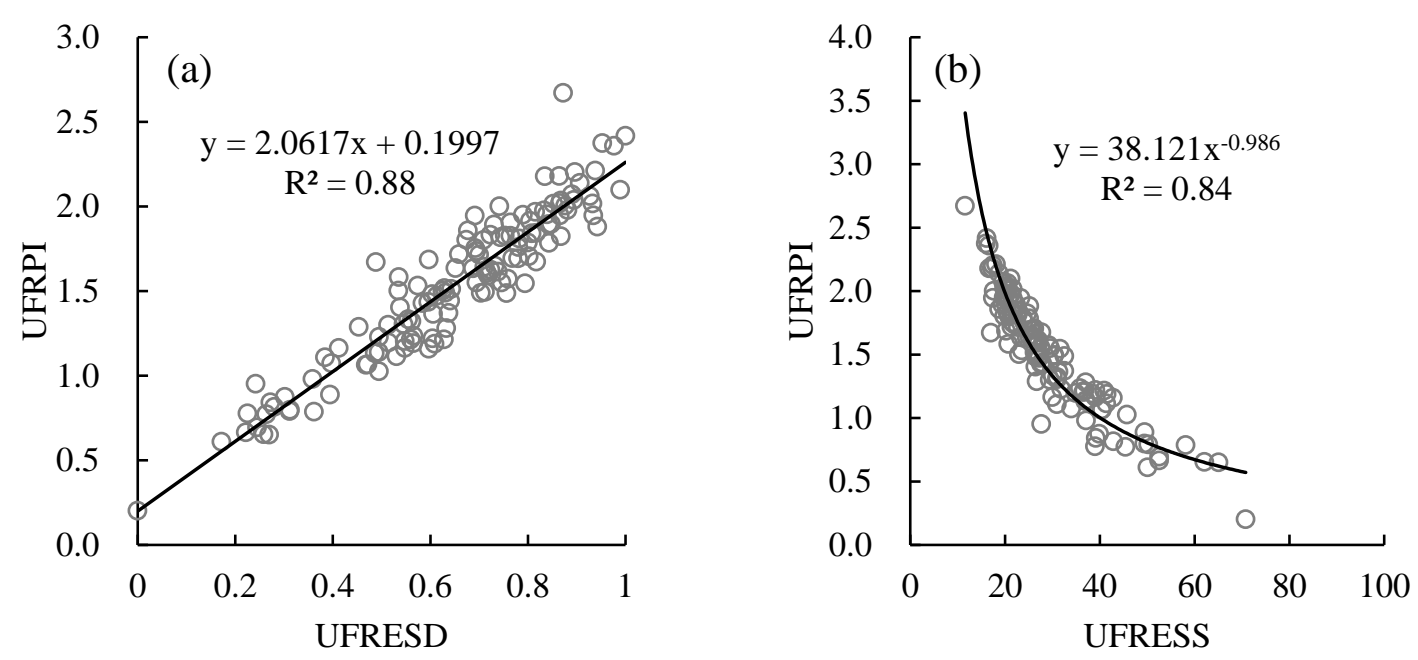

Figure 8. Scatter plot diagram and linear relationship between UFRPI and UFRESD (a); scatter plot diagram and non-linear relationship between UFRPI and UFRESS (b).

\subsection{The Role of Urban Green Space in Urban Flood Regulation}

Urban green space plays an important role in urban flood regulation through its capacity in runoff reduction, rainfall interception, and soil absorption [20,55]. It has become a vital indicator in urban spatial planning, especially in ecosystem services-based approaches [32]. Given that urban green space plays an important role in urban flood mitigation, it is necessary to analyze the role of green infrastructure in urban flood regulation priority identification [21,54]. Our results show that the districts with low UFRES supply have high impervious surface percentage and low green space percentage. Specifically, the urban green space percentage in the top 10 priority subdistricts were lower than $25 \%$ at the subdistrict scale, which is consistent with previous studies that found urban land patches with high runoff risk, mainly located in the center of Beijing, especially in the industrial zone or commercial zone where green space percentage is low $[33,50]$. This indicates that areas with a low proportion of urban green spaces should be upgraded to priority areas, in which to improve UFRES by constructing green infrastructure (e.g., rain gardens, green roofs, bioretention).

Moreover, there is a negative relationship between UFRES demand and green space percentage, which is consistent with previous studies [54,55], indicating that the subdistricts with a low proportion of green spaces also have high UFRES demand. However, our results also show that green space percentage in the subdistricts with an UFRES demand value higher than 0.45 is about $30 \%$ (Figure 9a), which indicates that there are spatial mismatches between UFRES supply and demand in the study area [62]. Additionally, when the green space ratio is lower than $40 \%$, the UFRPI declines quickly with the increase in green space percentage (Figure 9b). More specifically, when the green space percentage is higher than $40 \%$, the UFRPI value is close to 0 , which indicates that a subdistrict with more than $40 \%$ vegetation cover has the potential to adapt to a 10-year rainfall event (Figure 9b). But due to the influence of population and economic vulnerabilities, some subdistricts with poor green construction may have low demands for flood regulation services, which leads to the conclusion that there are quite a few subdistricts with low green space ratio and UFRPI [55]. Therefore, urban planners should pay more attention to understand the situation of green space in urban communities with different UFRES 
demand levels and their relationships. Maximizing the effect of urban green space will be helpful for urban planners to improve UFRES.
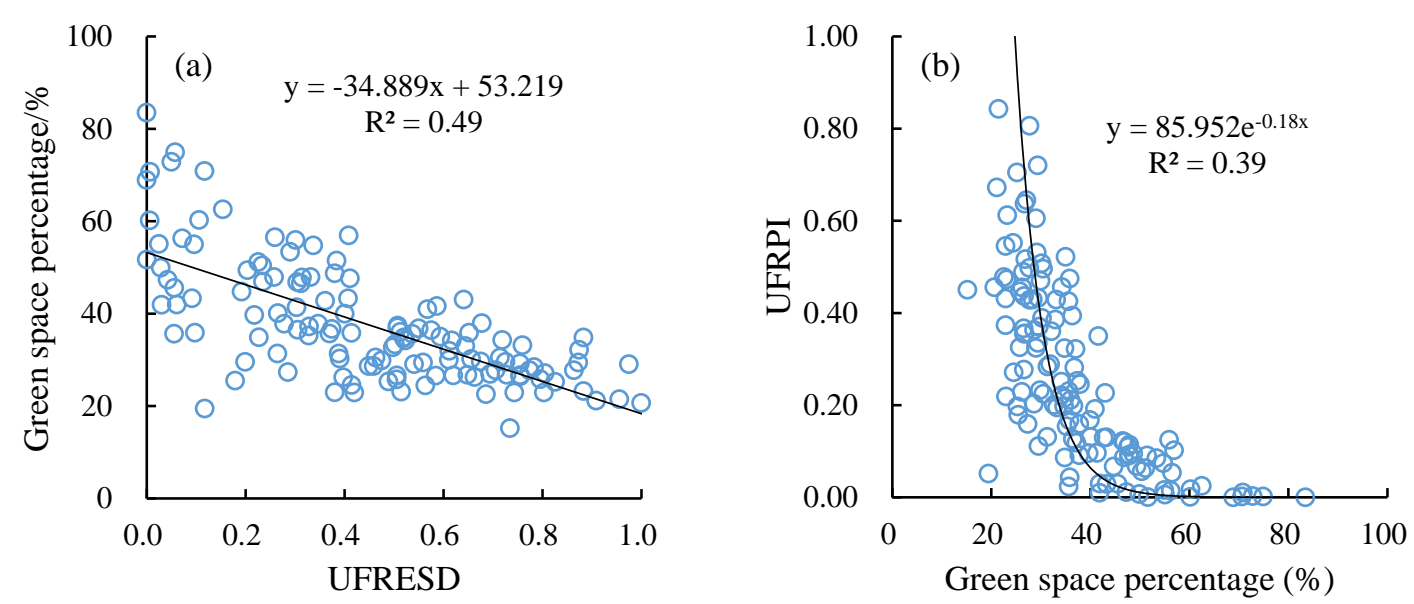

Figure 9. The relationship between urban green space percentage and (a) the demand for urban flood regulation ecosystem services (UFRESD), and (b) the urban flood regulation priority index (UFRPI).

\subsection{Limitations of the Approach and Future Perspectives}

In this study, we quantified the supply of and demand for UFRES in Beijing by using two widely used indicators and identified urban flood regulation priority areas. For the runoff simulation, we only had four rainfall return scenarios; the results showed that UFRESS decreased gradually with the increase of rainfall depth. However, previous studies found that the urban surface runoff reduction capacity initially increased and then decreased, and the runoff regulation capacity of urban green spaces was the strongest when the rainfall depth was $20 \mathrm{~mm}$ [32]. Thus, UFRESS needs to be simulated under more rainfall scenarios and soil moisture scenarios. Furthermore, urban runoff volume was also influenced by urban drainage systems, studies tend to use drainage data and hydrological models to simulate urban runoff and waterlogging at parcel scales [41]. However, drainage data was not used in our study area due to data accessibility at the city scale, which may have affected our simulation results to some extent.

Meanwhile, urban green spaces not only provide UFRES, but also play a role in air purification, urban heat island mitigation, carbon fixation, and recreational services [63-66]. However, there are tradeoffs and synergies between different ecosystem services, e.g., the tradeoff between urban flood regulation and urban landscape connectivity and the synergies with heat island mitigation and spatial purification [29]. In addition, the multifunctional spatial planning of urban green infrastructure is also determined by stakeholders' preferences, and considering stakeholders' preferences can maximize the benefits of ecosystem services provided by urban green infrastructure $[5,29]$. This study only considers UFRES while ignoring other types of ecosystem services. Yet it is worth analyzing whether other types of ecosystem services will be weakened by identifying priority areas of urban flood regulation to enhance urban flood regulation services.

Due to the complexity of urban land cover, high-resolution remote sensing images are needed to identify different urban green spaces, such as trees, grasslands, and shrubs, and to achieve accurate mapping of urban ecosystem services [67,68]. In this study, Landsat images with $30 \mathrm{~m}$ resolution were used to extract urban land cover components and to further evaluate UFRES, which may have resulted in some bias in the urban flood regulation service qualifications. However, it is difficult to obtain high-resolution land cover given the large extent of the study area. In the future, high-resolution remote sensing images and LiDAR data can be used to obtain finer information regarding the urban green space at small scale to achieve more accurate spatial mapping of ecosystem services [55]. 
Even though the traditional environmental engineering works can provide explicit design schemes for implementing urban green infrastructure, it is limited at local scales. With the approach taken in this study, a spatially explicit map for urban flood regulation priority at a reasonable scale (e.g., subdistrict scale, parcel scale) was easily obtained. Researchers could also design different rainfall scenarios according to their own need to evaluate UFRES supply and demand. Moreover, the approach integrates the UFRES demand and supply properly, which can avoid the spatial mismatch between UFRES supply and demand in urban planning, which is helpful to optimize layout of urban green space. In future urban planning, integrating an ecosystem services-based approach with environmental engineering works could help urban planners to design sustainable urban environments under multiple scales.

\section{Conclusions}

In this study, an ecosystem services-based approach was applied to identify urban flood regulation priority areas in Beijing. The runoff simulation results show that the urban surface runoff coefficient in Beijing increases with the increase of rainfall intensity. Urban impervious surface and green space play opposite roles in runoff mitigation. Due to different rainfall depth and land cover characteristics, UFRESS capacity varies among districts. The spatial divergence of UFRESS and UFRESD both shaped the urban flood regulation priority ranks. More specifically, urban green infrastructure updates to improve UFRESS capacity should be considered in the high-priority areas, located in Dongcheng and Xicheng Districts. Additionally, the UFRPI was an effective indicator to identify urban flood regulation priority areas, but green space percentage did not determine it directly due to urban population and economic vulnerabilities. Our study provides urban planners with a scientific basis for developing efficient flood mitigation strategies in the future.

Author Contributions: All authors substantially contributed to this article. Conceptualization, W.K.; methodology, X.L., W.K.; writing-original draft preparation, X.L.; writing-review and editing, X.L., W.K., F.S.; project administration, W.K.; funding acquisition, W.K. All authors have read and agreed to the published version of the manuscript.

Funding: This work was supported by the Key Project of Beijing Natural Science Foundation (8171004), the Strategic Priority Research Program of the Chinese Academy of Sciences (XDA23100201), and the General Program of National Natural Science Foundation of China (41871343).

Acknowledgments: Many thanks to anonymous reviewers for providing valuable opinions on revising the manuscript.

Conflicts of Interest: The authors declare no conflicts of interest.

\section{Appendix A}

Table A1. The economic score for different land use/cover.

\begin{tabular}{cc}
\hline Land Use/Cover Type & Economic Score \\
\hline Developed, high density $\left(\mathrm{a}_{\mathrm{ISA}}>80 \%\right)$ & 8 \\
Developed, moderate density $\left(50 \%<\mathrm{a}_{\mathrm{ISA}} \leq 80 \%\right)$ & 7 \\
Developed, low density $\left(20 \%<\mathrm{a}_{\mathrm{ISA}} \leq 50 \%\right)$ & 6 \\
Developed, open land $\left(\mathrm{a}_{\mathrm{ISA}} \leq 20 \%\right)$ & 4 \\
Undesignated & 3 \\
Cropland & 2 \\
Pasture land & 1 \\
\hline
\end{tabular}

\section{References}

1. Hirabayashi, Y.; Mahendran, R.; Koirala, S.; Konoshima, L.; Yamazaki, D.; Watanabe, S.; Kim, H.; Kanae, S. Global flood risk under climate change. Nat. Clim. Chang. 2013, 3, 816-821. [CrossRef] 
2. Wahl, T.; Jain, S.; Bender, J.; Meyers, S.D.; Luther, M.E. Increasing risk of compound flooding from storm surge and rainfall for major US cities. Nat. Clim. Chang. 2015, 5, 1093-1097. [CrossRef]

3. Buurman, J.; Babovic, V. Adaptation pathways and real options analysis: An approach to deep uncertainty in climate change adaptation policies. Policy Soc. 2016, 35, 137-150. [CrossRef]

4. Hallegatte, S.; Green, C.; Nicholls, R.J.; Corfee-Morlot, J. Future flood losses in major coastal cities. Nat. Clim. Chang. 2013, 3, 802-806. [CrossRef]

5. Hansen, R.; Pauleit, S. From multifunctionality to multiple ecosystem services? A conceptual framework for multifunctionality in green infrastructure planning for urban areas. Ambio 2014, 43, 516-529. [CrossRef]

6. United Nations. World Urbanization Prospects: The 2011 Revision; United Nations: New York, NY, USA, 2012.

7. Chen, S.Y.; Xue, Z.C.; Li, M.; Zhu, X.P. Variable sets method for urban flood vulnerability assessment. Sci. China Technol. Sc. 2013, 56, 3129-3136. [CrossRef]

8. Jacobson, C.R. Identification and quantification of the hydrological impacts of imperviousness in urban catchments: A review. J. Environ. Manag. 2011, 92, 1438-1448. [CrossRef]

9. Liu, Y.Z.; Bralts, V.F.; Engel, B.A. Evaluating the effectiveness of management practices on hydrology and water quality at watershed scale with a rainfall-runoff model. Sci. Total Environ. 2015, 511, 298-308. [CrossRef]

10. Kuang, W.H.; Chen, L.J.; Liu, J.Y.; Xiang, W.N.; Chi, W.F.; Lu, D.S.; Yang, T.R.; Pan, T.; Liu, A.L. Remote sensing-based artificial surface cover classification in Asia and spatial pattern analysis. Sci. China Earth Sci. 2016, 59, 1720-1737. [CrossRef]

11. Deng, X.J.; Xu, Y.P. Degrading flood regulation function of river systems in the urbanization process. Sci. Total Environ. 2018, 622, 1379-1390. [CrossRef]

12. Fletcher, T.D.; Shuster, W.; Hunt, W.F.; Ashley, R.; Butler, D.; Arthur, S.; Trowsdale, S.; Barraud, S.; Semadeni-Davies, A.; Bertrand-Krajewski, J.L.; et al. SUDS, LID, BMPs, WSUD and more-The evolution and application of terminology surrounding urban drainage. Urban Water J. 2015, 12, 525-542. [CrossRef]

13. Luederitz, C.; Brink, E.; Gralla, F.; Hermelingmeier, V.; Meyer, M.; Niven, L.; Panzer, L.; Partelow, S.; Rau, A.L.; Sasaki, R.; et al. A review of urban ecosystem services: Six key challenges for future research. Ecosyst. Serv. 2015, 14, 98-112. [CrossRef]

14. Verburg, P.H.; Koomen, E.; Hilferink, M.; Perez-Soba, M.; Lesschen, J.P. An assessment of the impact of climate adaptation measures to reduce flood risk on ecosystem services. Landsc. Ecol. 2012, 27, 473-486. [CrossRef] [PubMed]

15. Millennium Ecosystem Assessment. Ecosystems and Human Well-Being: Synthesis; Island Press: Washington, DC, USA, 2005.

16. de Groot, R.S.; Alkemade, R.; Braat, L.; Hein, L.; Willemen, L. Challenges in integrating the concept of ecosystem services and values in landscape planning, management and decision making. Ecol. Complex 2010, 7, 260-272. [CrossRef]

17. McPhearson, T.; Hamstead, Z.A.; Kremer, P. Urban ecosystem services for resilience planning and management in New York City. Ambio 2014, 43, 502-515. [CrossRef]

18. Fu, B.; Wang, Y.K.; Xu, P.; Yan, K. Mapping the flood mitigation services of ecosystems: A case study in the Upper Yangtze River Basin. Ecol. Eng. 2013, 52, 238-246. [CrossRef]

19. Kadykalo, A.N.; Findlay, C.S. The flow regulation services of wetlands. Ecosyst. Serv. 2016, 20, 91-103. [CrossRef]

20. Yang, L.Y.; Zhang, L.B.; Li, Y.; Wu, S.T. Water-related ecosystem services provided by urban green space: A case study in Yixing City (China). Landsc. Urban Plan. 2015, 136, 40-51. [CrossRef]

21. Zhang, B.; Xie, G.D.; Li, N.; Wang, S. Effect of urban green space changes on the role of rainwater runoff reduction in Beijing, China. Landsc. Urban Plan. 2015, 140, 8-16. [CrossRef]

22. Baró, F.; Palomo, I.; Zulian, G.; Vizcaino, P.; Haase, D.; Gomez-Baggethun, E. Mapping ecosystem service capacity, flow and demand for landscape and urban planning: A case study in the Barcelona metropolitan region. Land Use Policy 2016, 57, 405-417. [CrossRef]

23. Burkhard, B.; Kroll, F.; Nedkov, S.; Muller, F. Mapping ecosystem service supply, demand and budgets. Ecol. Indic. 2012, 21, 17-29. [CrossRef]

24. Goldstein, J.H.; Caldarone, G.; Duarte, T.K.; Ennaanay, D.; Hannahs, N.; Mendoza, G.; Polasky, S.; Wolny, S.; Daily, G.C. Integrating ecosystem-service tradeoffs into land-use decisions. Proc. Natl. Acad. Sci. USA 2012, 109, 7565-7570. [CrossRef] [PubMed] 
25. Tammi, I.; Mustajarvi, K.; Rasinmaki, J. Integrating spatial valuation of ecosystem services into regional planning and development. Ecosyst. Serv. 2017, 26, 329-344. [CrossRef]

26. Woodruff, S.C.; BenDor, T.K. yy Ecosystem services in urban planning: Comparative paradigms and guidelines for high quality plans. Landsc. Urban Plan. 2016, 152, 90-100. [CrossRef]

27. Gret-Regamey, A.; Altwegg, J.; Siren, E.A.; van Strien, M.J.; Weibel, B. Integrating ecosystem services into spatial planning-A spatial decision support tool. Landsc. Urban Plan. 2017, 165, 206-219. [CrossRef]

28. Turkelboom, F.; Leone, M.; Jacobs, S.; Kelemen, E.; Garcia-Llorente, M.; Baro, F.; Termansen, M.; Barton, D.N.; Berry, P.; Stange, E.; et al. When we cannot have it all: Ecosystem services trade-offs in the context of spatial planning. Ecosyst. Serv. 2018, 29, 566-578. [CrossRef]

29. Meerow, S.; Newell, J.P. Spatial planning for multifunctional green infrastructure: Growing resilience in Detroit. Landsc. Urban Plan. 2017, 159, 62-75. [CrossRef]

30. Babí Almenar, J.; Rugani, B.; Geneletti, D.; Brewer, T. Integration of ecosystem services into a conceptual spatial planning framework based on a landscape ecology perspective. Landsc. Ecol. 2018, 33, $2047-2059$. [CrossRef]

31. Bai, Y.; Wong, C.P.; Jiang, B.; Hughes, A.C.; Wang, M.; Wang, Q. Developing China's ecological redline policy using ecosystem services assessments for land use planning. Nat. Commun. 2018, 9, 3034. [CrossRef]

32. Snall, T.; Lehtomaki, J.; Arponen, A.; Elith, J.; Moilanen, A. Green infrastructure design based on spatial conservation prioritization and modeling of biodiversity features and ecosystem services. Environ. Manag. 2016, 57, 251-256. [CrossRef]

33. Yao, L.; Chen, L.D.; Wei, W.; Sun, R.H. Potential reduction in urban runoff by green spaces in Beijing: A scenario analysis. Urban For. Urban Green. 2015, 14, 300-308. [CrossRef]

34. Beijing Statistical Bureau. Beijing Statistical Yearbook; China Statistics Press: Beijing, China, 2019. (In Chinese)

35. Hao, P.Y.; Niu, Z.; Zhan, Y.L.; Wu, Y.C.; Wang, L.; Liu, Y.H. Spatiotemporal changes of urban impervious surface area and land surface temperature in Beijing from 1990 to 2014. Gisci. Remote Sens. 2016, 53, 63-84. [CrossRef]

36. Kuang, W.H.; Chi, W.F.; Lu, D.S.; Dou, Y.Y. A comparative analysis of megacity expansions in China and the U.S.: Patterns, rates and driving forces. Landsc. Urban Plan. 2014, 132, 121-135. [CrossRef]

37. Kuang, W.H.; Yang, T.R.; Liu, A.L.; Zhang, C.; Lu, D.S.; Chi, W.F. An EcoCity model for regulating urban land cover structure and thermal environment: Taking Beijing as an example. Sci. China Earth Sci. 2017, 60, 1098-1109. [CrossRef]

38. Sun, Y.; Zhang, X.B.; Ren, G.Y.; Zwiers, F.W.; Hu, T. Contribution of urbanization to warming in China. Nat. Clim. Chang. 2016, 6, 706. [CrossRef]

39. Zhu, L.T.; Chen, Y.S.; Yan, R.R.; Shen, T.; Jiang, L.; Wang, Y. Characteristics of precipitation and temperature changes in Beijing City during 1951-2010. Resour. Sci. 2012, 34, 1287-1297. (In Chinese)

40. Li, C. Ecohydrology and good urban design for urban storm water-logging in Beijing, China. Ecohydrol. Hydrobiol. 2012, 12, 287-300. (In Chinese) [CrossRef]

41. Li, R.; Pan, X.Y.; Di, S.C.; Yang, M.Y.; Su, Y. Diagnostic analysis of the waterlogging influence factors in Beijing City: A case study of Shangqingqiao catchment. J. Nat. Resour. 2018, 33, 1940-1952. (In Chinese) [CrossRef]

42. Fan, F.L.; Deng, Y.B.; Hu, X.F.; Weng, Q.H. Estimating composite curve number using an improved SCS-CN method with remotely sensed variables in Guangzhou, China. Remote Sens. 2013, 5, 1425-1438. [CrossRef]

43. Zhang, C.; Chen, Y.L.; Lu, D.S. Detecting fractional land-cover change in arid and semiarid urban landscapes with multitemporal Landsat Thematic Mapper imagery. Gisci. Remote Sens. 2015, 52, 700-722. [CrossRef]

44. $\mathrm{Xu}, \mathrm{H}$.Q. Modification of normalised difference water index (NDWI) to enhance open water features in remotely sensed imagery. Int. J. Remote Sens. 2006, 27, 3025-3033. [CrossRef]

45. Lu, D.S.; Weng, Q.H. Use of impervious surface in urban land-use classification. Remote Sens. Environ. 2006, 102, 146-160. [CrossRef]

46. Ning, J.; Liu, J.Y.; Kuang, W.H.; Xu, X.L.; Zhang, S.W.; Yan, C.Z.; Li, R.D.; Wu, S.X.; Hu, Y.F.; Du, G.M.; et al. Spatiotemporal patterns and characteristics of land-use change in China during 2010-2015. J. Geogr. Sci. 2018, 28, 547-562. [CrossRef]

47. Kuang, W.H.; Liu, J.Y.; Dong, J.W.; Chi, W.F.; Zhang, C. The rapid and massive urban and industrial land expansions in China between 1990 and 2010: A CLUD-based analysis of their trajectories, patterns, and drivers. Landsc. Urban Plan. 2016, 145, 21-33. [CrossRef] 
48. Resource and Environment Data Cloud Platform. Available online: http://www.resdc.cn/data.aspx?DATAID= 145 (accessed on 13 January 2020).

49. Beijing Municipal Bureau of Statistics. Available online: http://www.beijing.gov.cn/zfxxgk/110037/pc53/201212/17/content_358394.shtml (accessed on 13 January 2020).

50. Yao, L.; Wei, W.; Yu, Y.; Xiao, J.; Chen, L.D. Rainfall-runoff risk characteristics of urban function zones in Beijing using the SCS-CN model. J. Geogr. Sci. 2018, 28, 656-668. [CrossRef]

51. Cronshey, R.; McCuen, R.H.; Miller, N.; Rawls, W.; Robbins, S.; Woodward, D. Urban Hydrology for Small Watersheds, 2nd ed.; Technical Release 55; U.S. Dept. of Agriculture, Natural Resources Conservation Service, Conservation Engineering Division: Reston, VA, USA, 1986.

52. Li, C.L.; Liu, M.; Hu, Y.M.; Shi, T.; Qu, X.Q.; Walter, M.T. Effects of urbanization on direct runoff characteristics in urban functional zones. Sci. Total Environ. 2018, 643, 301-311. [CrossRef]

53. Fu, S.H.; Wang, H.Y.; Wang, X.L.; Yuan, A.P.; Lu, B.J. The runoff curve number of SCS-CN method in Beijing. Geogr. Res. 2013, 32, 797-807. (In Chinese) [CrossRef]

54. Shen, J.; Du, S.; Huang, Q.; Yin, J.; Zhang, M.; Wen, J.; Gao, J. Mapping the city-scale supply and demand of ecosystem flood regulation services: A case study in Shanghai. Ecol. Indic. 2019, 106. [CrossRef]

55. Maragno, D.; Gaglio, M.; Robbi, M.; Appiotti, F.; Fano, E.A.; Gissi, E. Fine-scale analysis of urban flooding reduction from green infrastructure: An ecosystem services approach for the management of water flows. Ecol. Model. 2018, 386, 1-10. [CrossRef]

56. Wang, Q.; Zhang, X.X.; Wei, M.J.; Zhou, Y.W.; Li, P.; Bai, G.Y. Research summary of planning and design standards for storm water system in Beijing city. Water Waste Eng. 2011, 37, 34-39. (In Chinese)

57. Stürck, J.; Poortinga, A.; Verburg, P.H. Mapping ecosystem services: The supply and demand of flood regulation services in Europe. Ecol. Indic. 2014, 38, 198-211. [CrossRef]

58. Dong, W.H.; Liu, Z.; Zhang, L.J.; Tang, Q.H.; Liao, H.; Li, X.E. Assessing heat health risk for sustainability in Beijing's urban heat island. Sustainability 2014, 6, 7334-7357. [CrossRef]

59. Zachos, L.G.; Swann, C.T.; Altinakar, M.S.; McGrath, M.Z.; Thomas, D. Flood vulnerability indices and emergency management planning in the Yazoo Basin, Mississippi. Int. J. Disast. Risk. Reduct. 2016, 18, 89-99. [CrossRef]

60. Anselin, L. Local indicators of spatial association-LISA. Geogr. Anal. 1995, 27, 93-115. [CrossRef]

61. Fernandez, I.C.; Wu, J.G. A GIS-based framework to identify priority areas for urban environmental inequity mitigation and its application in Santiago de Chile. Appl. Geogr. 2018, 94, 213-222. [CrossRef]

62. Baró, F.; Haase, D.; Gómez-Baggethun, E.; Frantzeskaki, N. Mismatches between ecosystem services supply and demand in urban areas: A quantitative assessment in five European cities. Ecol. Indic. 2015, 55, 146-158. [CrossRef]

63. Lovell, S.T.; Taylor, J.R. Supplying urban ecosystem services through multifunctional green infrastructure in the United States. Landsc. Ecol. 2013, 28, 1447-1463. [CrossRef]

64. Kremer, P.; Hamstead, Z.A.; McPhearson, T. The value of urban ecosystem services in New York City: A spatially explicit multicriteria analysis of landscape scale valuation scenarios. Environ. Sci. Policy 2016, 62, 57-68. [CrossRef]

65. Gillner, S.; Vogt, J.; Tharang, A.; Dettmann, S.; Roloff, A. Role of street trees in mitigating effects of heat and drought at highly sealed urban sites. Landsc. Urban Plan. 2015, 143, 33-42. [CrossRef]

66. Grote, R.; Samson, R.; Alonso, R.; Amorim, J.H.; Carinanos, P.; Churkina, G.; Fares, S.; Le Thiec, D.; Niinemets, U.; Mikkelsen, T.N.; et al. Functional traits of urban trees: Air pollution mitigation potential. Front. Ecol. Environ. 2016, 14, 543-550. [CrossRef]

67. Southon, G.E.; Jorgensen, A.; Dunnett, N.; Hoyle, H.; Evans, K.L. Biodiverse perennial meadows have aesthetic value and increase residents' perceptions of site quality in urban green-space. Landsc. Urban Plan. 2017, 158, 105-118. [CrossRef]

68. Davies, Z.G.; Edmondson, J.L.; Heinemeyer, A.; Leake, J.R.; Gaston, K.J. Mapping an urban ecosystem service: Quantifying above-ground carbon storage at a city-wide scale. J. Appl. Ecol. 2011, 48, 1125-1134. [CrossRef]

(C) 2020 by the authors. Licensee MDPI, Basel, Switzerland. This article is an open access article distributed under the terms and conditions of the Creative Commons Attribution (CC BY) license (http://creativecommons.org/licenses/by/4.0/). 